\title{
Refugee immigration and the growth of low-wage work in the EU15
}

\author{
Lars Fredrik Andersson ${ }^{1 *}\left(\mathrm{D}\right.$, Rikard Eriksson ${ }^{2}$ and Sandro Scocco ${ }^{3}$
}

\author{
* Correspondence: lars-fredrik. \\ andersson@umu.se \\ ${ }^{1}$ Department of Economic History \& \\ Centre for Demographic and \\ Ageing Research, Umeå University, \\ Biblioteksgränd 6, SE-90187 Umeå, \\ Sweden \\ Full list of author information is \\ available at the end of the article
}

\begin{abstract}
Our paper focuses on current trends in refugee migration and job polarization. In so doing, we assess the role of refugee migration in relation to institutional, technologicalty 1 and globalization factors in an effort to trace the factors underlying the growth of low-paying occupations in EU 15 between 1995 and 2017. Our empirical findings suggest that refugee migration has a small but positive and statistically significant impact on the growth of low-wage occupations in the EU 15 as a whole. However, the effect is attributed to Southern Europe and the UK and Irish economies. Despite hosting relatively large numbers of refugee migrants, the effects in the Nordic countries and Continental Europe are negligible, if present, and non-existent in the long run (5 years). When including all migrant workers, we find a limited impact on the growth of low-wage work in general, while the impact of immigrant workers from low-income third party countries becomes positive for the UK and Irish economy, but less for other European macro-regions. This suggests that institutional settings can play an important role in how the economy adjusts to migration. It also suggests that traditional fiscal cost calculations in relation to migration are often overestimated, as they implicitly build on the assumption that refugees and general immigration have great impacts on the growth of low-wage occupations.

Keywords: Refugees, Immigration, Low-wage jobs, EU

JEL classifications: F22, J31, R23
\end{abstract}

\section{Introduction}

In recent years, the labour market consequences of migration have been widely discussed in the EU. Since the increase in refugee immigration in $2015 / 16$, there has been a polarized debate over immigration and potential solutions (Hatton, 2016). Although the peak of the high inflow of refugees is behind us, many of those who arrived in Europe are likely to stay - with expected long-term economic effects on the host countries (OECD, 2017a). As shown by Dustmann and Frattini (2011), the employment gaps between native and foreign labour are substantial in general, and even more so for low-skilled immigrants. Such immigrants tend to be sorted into less well-paid forms of employment with high shares of part-time and temporary contracts, which is argued to reduce both income and tax revenues (cf. Ekberg, 2011).

(c) The Author(s). 2019 Open Access This article is distributed under the terms of the Creative Commons Attribution 4.0 International License (http://creativecommons.org/licenses/by/4.0/), which permits unrestricted use, distribution, and reproduction in any medium, provided you give appropriate credit to the original author(s) and the source, provide a link to the Creative Commons license, and indicate if changes were made. 
Prior research on labour market participation, however, has shown great heterogeneity across nations and immigrant cohorts, resulting in largely different effects of immigration (Seukwa, 2013). While segregation between natives and foreign workers seems to decline due to occupational upgrading for immigrants on average, immigrants from poor countries with limited resources are less likely to climb the income ladder (Rodriguez-Planas, 2012). Hence, it is basically immigrants from outside the EU, such as refugees, who drive the substantial differences between native and foreign workers in the EU (Dustmann \& Frattini, 2011). As such, refugee migration shapes an exogenous inflow of potential workers that could be argued to be more supply than demand driven, for example, intraEU labour mobility.

In a paper on the impact of immigrants on the output mix, González and Ortega (2011) show that unskilled immigrants who increased the supply of labour did not change the output mix, but rather the skill intensities within industries. Thus, an increasing immigrant labour supply tends to have a moderate impact on natives' wages if it is absorbed by changes in relative factor intensity. As shown by Dustmann and Glitz (2015), this applies especially to new firms. If third country nationals, such as refugees, are imperfect substitutes for native workers, this helps to explain why wages and employment rates for natives tend to be less affected by immigrants. However, it also raises the question of how the overall employment structure is affected: Are native workers, as suggested by Ottaviano and Peri (2012), reallocated from low-skilled and low-paid occupations into more qualified occupations or should one expect, as Lewis (2011) does, that the low-wage sector will grow in size by adopting less skilled-biased technology?

To address this issue, the present paper will focus on how refugees influenced the share of low-wage occupations in the EU15 during the years 1995 to 2017 - a period when the low-wage sector expanded and major changes in refugee immigration took place. This period was also characterized by growing intra-EU labour migration and increasing numbers of immigrants from outside the EU "third country nationals" without international protection status. The paper considers these various types of immigration by including the wider scope of intra-EU labour migration, and immigration from outside EU that includes both people with and without full refugee status. In this way, we provide a broader account of the effects of immigration on the growth of low-wage work.

By assessing the impact of refugees along with other forms of immigration on low-wage jobs, we relate our analysis to current discussions on job polarization. While the main argument is related to technological changes, globalization and inequality, much less interest has been paid to the potential immigrant-induced change in skill composition in the EU context (Fernandez-Macias \& Hurley, 2017; Goos, Manning, \& Salomons, 2009). For the US, a study by Autor and Dorn (2013) shows that growing low-skilled migration had a much weaker impact than technological factors did on the expansion of low-skilled occupations. But for the EU15 countries, which have largely different institutional settings and immigrant structures than the US, the impact of refugee and other forms of immigration may be different. A study on immigrant effects on the low-wage sector in EU15 - such as the present one - may help to narrow this gap. We believe that failure to address this issue may furthermore overlook the potential impact that immigrant 
work segregation has on the calculated fiscal impact of immigration. This body of literature typically assumes that immigrants' low-wage occupational bias translates into a negative redistribution effect between natives and refugees and increases the redistribution from natives to refugees (Ekberg, 2011). By addressing the validity of the implicit assumption in this literature, the present study can help to increase our understanding of whether the redistributive effect really can be interpreted as a cost.

The remainder of the paper is structured as follows. In the next section, our analytical framework is outlined. In the third section, the scope and structure of immigration and low-wage work are outlined. In the fourth section, the research design is presented, and in the fifth section our empirical findings are reported. We offer our conclusions in the sixth section.

\section{Analytical framework}

Theoretically, the impact of immigrant inflow on natives' labour market opportunities has been seen within a standard neoclassical framework, where a labour supply shock generated by immigrants triggers a reduction in the wages or employment of native workers (Borjas, 2003; Card, 2001, 2005). The finding that immigration has a weak, if any, impact on the native population's wages and employment rate has, however, led researchers to consider alternative adjustment mechanisms to immigration (Eva \& Tritah, 2016). By recognizing how open economies are highly interconnected with trade, recent work has focused on the adjustment mechanism described by the so-called Rybczynski theorem (Rybczynski, 1955). In principle, the theorem demonstrates how changes in a given endowment affect the outputs of goods when full employment is maintained in an open economy. The mechanism is that the immigration of workers, providing they have a different skill composition (higher or lower human capital $[\mathrm{HC}]$ in relation to native workers), will expand the sector that uses that particular factor (high/low human capital) intensively. Due to the adjustment mechanism, the factor prices in the open economy will be unaffected, while the inflow of immigrants will be absorbed by changing the structure of production (González \& Ortega, 2011). A more abundant supply of immigrant workers with lower human capital (relative native workers) may further invoke adjustment of labour demand. By adapting to an increasing supply of workers with low HC, such as an exogenous inflow of immigrants with lower skills than native workers, firms have fewer incentives to adopt skilled-biased technology (Lewis, 2011). The given implication of this is that the low-wage sector needs to grow in order to absorb the increasing labour supply and avoid unemployment. Given that immigrants, and refugees in particular, tend to have lower skills/human capital than native workers, our first hypothesis is as follows:

H1: Immigration will have a positive and significant impact on the growth of the low-wage sector.

An exogenously driven immigration-induced labour supply shock, such as increasing refugee migration, may however also enable a reallocation of native workers to more skill-demanding occupations, as less-skilled immigrants can take over low-skilled, manual work. This is because when the economy expands, natives are offered new career possibilities when low-skilled immigrants take on less attractive work. The result is that 
the economy's job and wage structure tends to be largely unaffected, or at least that the low-wage sector will not expand as a result of exogenous immigration. However, this type of process also entails that occupational segregation might be more pronounced with reinforced labour market segmentation, as fewer natives will have employment in the low-wage sector and migrants will be overrepresented. Still, it is argued that the negative effect of immigration on native workers is negligible (Dustmann, Hatton, \& Preston, 2005; Foged \& Peri, 2016; Ottaviano \& Peri, 2012).

In an early seminal study on migration and economic growth, Brinley (1954) observed how migration to the US in the late 19th and early twentieth century coincided with investment upswings and the introduction of new capital structures. The adjustment of capital towards new innovative and labour-saving machinery and equipment (e.g., electricity, chemistry) coincided with the inflow of cheap, low-skilled labour leaving south-east Europe at the time. This process led to the 'widening' of capital structures, which benefited the productive powers of the US economy. These ideas were later taken up by Tabellini (2018), who further argues that immigrants should be considered imperfect substitutes, because natives can work in both the skilled and the unskilled sector, while immigrants tend to be barred from skilled occupations (given that immigrants have lower skills). Capital, on the other hand, is endogenously supplied and can produce an endogenous response from the production side, which can accommodate the inflow of immigrants via new plants (workplaces). Under these conditions, results from micro-level studies can be accommodated within a macroeconomic model. As Tabellini (2018, pp. 2-3) concludes, "In this case, immigration is absorbed by two distinct channels: first, through an increase in firms' investment, as before; second, via occupational mobility of natives who tend to take up jobs where they have a comparative advantage relative to immigrants". Hence, relative unemployment among immigrants is mainly attributed to weak growth or barriers to social mobility. Given that line of reasoning, we hypothesize the following:

H2: Immigration will have an insignificant impact on the growth of the low-wage sector.

As shown in previous studies on occupational segregation, if exogenously driven refugee immigration from low-income countries outside the EU increases, this will generally translate into a larger immigrant share in low-skilled occupations (RodriguezPlanas, 2012). Studies on wage gaps also show how primarily non-European migrants end up in low-wage work. In France, for instance, first-generation immigrant men from Europe do not experience any earning gap, while workers from sub-Saharan Africa earn much less than natives do. In the UK, the earning gap is greater compared to that in Germany and France (Algan, Dustmann, Glitz, \& Manning, 2010). And for Italy, Venturini and Villosio (2006) show a substantial wage gap over time between natives and foreign workers. African workers are the least well-paid, while East Europeans tend to converge on natives' wages. In the present paper, we differentiate between labour migration within the common EU labour market, which in a labour market context should be regarded as one single market with free mobility similar to the US, and external EU immigration that is regulated. We assume that EU mobility is primarily demand driven and that workers will move where there is a demand for their skills and where 
capital can absorb an increasing supply. This will hold true especially when workers expect higher living standards as a result of mobility (Harris \& Todaro, 1970). Because the problem is labour shortage, this predicts that sectors that would otherwise experience expansion problems can expand. In turn, an exogenously driven immigrationinduced growth in the labour supply, such as refugees, will, if anything, force an adjustment in capital rather than responding to demand (Tabellini, 2018).

The adjustment of capital may also interact with the general growth of the capital stock. In stagnating economies with low firm investments, adaptation according the first hypothesis - seems more likely as the adjustment of capital will be slow, if it occurs at all. If that holds true, the second hypothesis would be more likely to apply in expanding markets with high firm investments. The second hypothesis further underlines the role of social mobility, where native workers may climb up the ladder owing to their comparative advantages over immigrants. Such an adjustment process is related to more general issues like income distribution, residential segregation and early educational selection. All of them are likely to impede upward mobility among native workers in lowskilled occupations.

In this context Hypothesis 1 and 2 are not mutually exclusive, but complementary, and can be interpreted as different mechanisms of adjustment to migration defined by country-specific institutions. Countries with institutional settings that induce high social mobility will adjust to migration in a different way than countries with low social mobility, where the latter will adjust to migration by expanding the low-wage sector. This can be graphically illustrated as in Fig. 1.

To highlight institutional differences, we make use of the division of European countries proposed by Farkas (2016), who distinguishes between the Nordic/ Scandinavian, North-western/UK \& Ireland, Mediterranean/Southern Europe, and Continental/Central European models of capitalism. However, it should be noted that distinguishing between macro-regions is a way to indicate potential differences in adjustment mechanisms, rather than an examination of the impact of institutional differences.

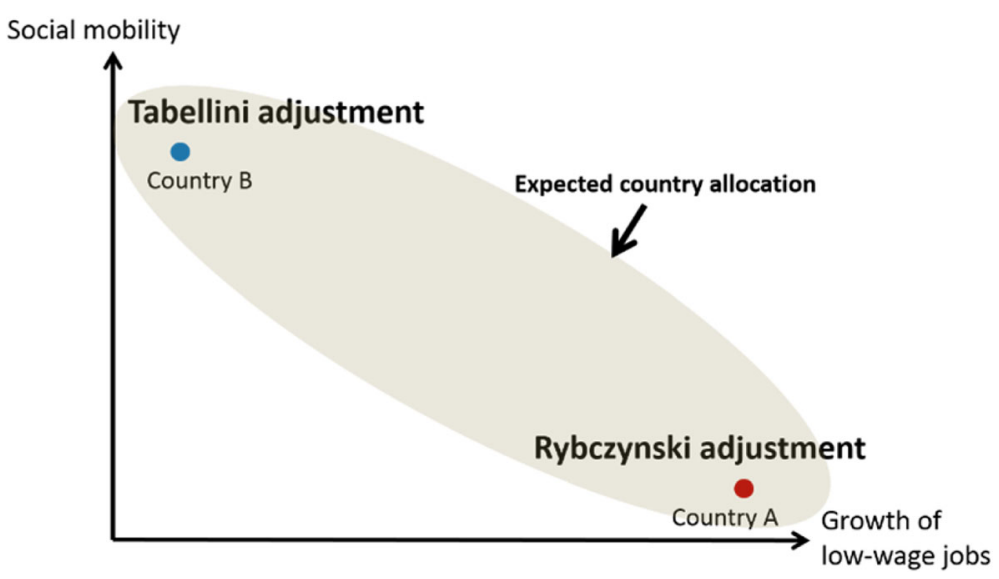

Fig. 1 Illustration of different mechanisms of adjustment to migration 


\section{Research design \\ Data}

To assess the impact of refugee migration on low-wage occupations in the EU, we have used data from the European labour force survey 1995-2017. The rationale for analysing this period is that a considerable amount of data is missing prior to 1995 and because countries like Sweden, Finland and Austria did not become members until that year. The database includes a wide array of individual-level information (e.g., occupation, country of birth, etc.) that can be linked to each of the member states. As the discussion on occupational changes mainly refers to countries that could be considered the "Old EU", we include 16 countries (i.e., EU15 plus Norway and Switzerland, but excluding Luxemburg), giving us a total of 368 country-year observations. Still, information on occupations was missing for Sweden, Finland and Switzerland for some years (1995-1996, 1995-1996 and 1995, respectively), meaning that we ended up with 363 country-year observations.

\section{Dependent variable}

Our dependent variable is the annual share of low-wage occupations compared to total employment in each country. In accordance with previous studies on the EU (e.g., Goos et al., 2009; Goos, Manning, \& Salomons, 2014), we have defined low-wage occupations as the share of workers belonging to the 1-digit occupation codes (ISCO) 5 and 9. That is, service workers and shop and market sales workers (ISCO-5) and elementary occupations (ISCO-9). Although the income levels within these groups vary across countries due to different levels of purchasing power in each economy, ${ }^{1}$ it is still argued that this generic definition of low-wage occupations is better than making specific definitions for each country, as it will facilitate comparison across countries and continents (cf. Goos et al., 2014).

\section{Independent variables}

The key explanatory variables are all related to the exposure of immigrants in each national economy. Our main focus is on refugee immigrants. The reason is theoretical, in that refugees most accurately reflect an exogenously driven supply shock to the labour market. According to the UNHCR definition, refugees (incl. Refugee-like situations) are people who are recognized as refugees under the 1951 Convention Relating to the Status of Refugees or its 1967 Protocol, the 1969 Organization of African Unity Convention Governing the Specific Aspects of Refugee Problems in Africa, people recognized as refugees in accordance with the UNHCR statute, people granted refugee-like humanitarian status, and people provided temporary protection. Data on refugees are reported by UN/UNHCR. In the present paper, the stock of refugees is expressed as a share of the total population, labelled "REFMIG". Refugees, including those with subsidiary protection, have full access to the labour market. The same does not always apply to asylum seekers (OECD, 2017b), who are therefore omitted from the analysis.

\footnotetext{
${ }^{1}$ For example, the mean income of elementary occupations (ISCO-9) in the total sample is $65 \%$ of the mean income of all workers in the EU. For service workers (ISCO-5), the average income discrepancy in the EU is $68 \%$ of the mean income, while it is lowest in the UK and Ireland, with $61 \%$ of the mean income, and highest in the Nordic countries, with $75 \%$ of the mean income.
} 
Although our main focus is on refugees, we acknowledge the importance of considering the far greater number of non-refugee immigrants during the period under study (1995-2017). In an effort to consider their labour market impact, we separate between within-EU immigration and non-EU immigration. The non-EU migrants are divided into three sub-groups, representing high-income countries (equal or greater the average income of EU15), middle-income countries (EU28 and non-EU countries with income levels equal to or greater than average of EU25, but less than EU15), and low-income countries (remaining countries with lower income levels than EU25). The idea behind this distinction is that the mobility of immigrants from high-income countries is largely demand driven - similar to the intra-EU15 labour mobility. The mobility of immigrants from middle-income countries is considered largely demand driven, but they are less skilled on average than the former group. The mobility of the third group of immigrants from low-income countries is considered a mix of the demand- and supplydriven factors of less skilled immigrants. In order to make the distinction empirically, we use the OECD Database on immigrants in OECD Countries to assess employment rate by origin and UN population census data to identify the economic active population by country of origin for every fifth year. GDP per capita is used as the income measure for sub-group division, except for fuel-exporting countries, which are placed in the third (low-income) category. In the empirical analysis, the immigrants from high-income countries (within \& outside EU15) are pooled together to represent demand-driven, high-skilled labour immigration, labelled "LABMIG-HIGH" and expressed as a share of total employment. Immigrants from middle-income countries (within \& outside EU25) are pooled together to represent a demand-driven, mid-skilled labour immigration, labelled "LABMIG-MID" and expressed as a share of total employment. The third group, immigrants from low-income countries outside the EU25, is labelled "LABMIG-LOW" and expressed as a share of total employment. Migration from low-income countries partly overlaps refugee immigration, though it is different in a number of respects. The international protection status is obvious, but from an analytical standpoint, it is important to distinguish between the two. Third country nationals without international protection status may have employment permits, study visas and family reunification status that is related to the demand- rather than to the supply-driven forces of immigration.

Apart from migration flows, a number of additional factors identified in the literature might influence the growth of low-wage occupations (cf. Fernandez-Macias \& Hurley, 2017; Goos et al., 2009, 2014; Tabellini, 2018); see Table 4 in the Appendix for definitions and sources. We have divided them into four main groups. First, institutional factors are related to the regulations of labour markets. We first add a dummy (EU25+) capturing the year when a total of 10 new member states enter the EU, as this could influence the mobility of workers within the common market. The indicator CollBar captures the adjusted bargaining cover rate as an annual proportion of all workers, as this is likely to influence both the level and distribution of incomes in an economy. Moreover, regulation of employment conditions may have an effect on low-wage occupations, as stronger regulations limit the growth of temporary and part-time positions, which are common among low-wage occupation. Hence, the variables EmpDis and EmpTemp, respectively, capture the degree to which each economy regulates the protection against dismissals and temporary employment. Second, we created a number of 
indicators related to the pressure that globalization processes might have on the labour market. ImpShare is the annual value of imports in relation to GPD in percentages, as that captures the degree of foreign competition. Moreover, outgoing foreign direct investments (FDI) as a proportion of GDP might co-determine to what extent certain occupations face the risk of being outsourced. The third group of indicators relate to technology. The variables used to proxy this are: Annual labour productivity $(L P)$ defined as GDP per capita, human capital $(H C)$ defined as the share of workers with at least a 3-year university diploma, technological change (TechChange) defined as the annual factor productivity growth, and investments (INV) as a share of GDP. Finally, we control for the annual relative wage (RelWage) in each economy as a proportion of each country's wage in relation to the EU average in percentages, the income distribution based on the Gini-coefficient, and the size of the economy by the annual number of employed in thousands (LMsize).

\section{Model}

Due to the panel structure of the data (i.e., multiple country-year observations), we resort to a fixed-effects (FE) model with a full set of time-dummies to capture unobserved time-specific heterogeneity (e.g., non-observed chocks in specific years, for example, the recession in 2008-2009 and upsurges in migration inflows due to conflicts). Compared to a pooled OLS, this model emphasizes the within-case variation in the data. Hence, it controls for unobserved country-specific unobservables and could be considered more efficient than a between-case estimator (a Hausman test reveals that the FE model is preferable over an RE model). This is particularly crucial in our case, as we do not have detailed information on the industry structure of each economy, although it is reasonable to expect that occupations in certain industries may be more sensitive to migration than other sectors (González \& Ortega, 2011). The model is specified as follows:

$$
\begin{aligned}
L_{W O}= & \beta_{0}+\beta_{1}\left[\text { Refugees }_{i t-1}\right]+\beta_{2}\left[\text { Institutions }_{i t-1}\right]+\beta_{3}\left[\text { Globalization }_{i t-1}\right] \\
& +\beta_{4}\left[\text { Technology }_{i t}\right]+\beta_{5}\left[\text { Controls }_{i t-1}\right] v_{i}+\varepsilon_{i t}
\end{aligned}
$$

where $L W O_{i t}$ is the share of low-wage occupations in country ${ }_{\mathrm{i}}$ in time ${ }_{\mathrm{t}}$ Refugees $_{i t-1}$ represent the exposure of refugee immigrants in each economy measured in $\mathrm{t}-1$ to mitigate the impact of reversed causality. Instititions ${ }_{i t-1}$, Globalization ${ }_{i t-1}$, Technology ${ }_{i t-1}$, and Controls ${ }_{i t-1}$, each represent a vector of variables capturing the role of institutions, globalization, technology and control variables presented above. $v_{i}$ is the unobserved country-specific effect, and it is the unobserved random error term. Based on the correlation matrix and additional VIF tests, no serious cases of mulitcollinearity were detected. Moreover, because the within-case estimator stresses the dynamics within cases over time, rather than the inter-country variation, it cannot include time-invariant variables and produces imprecise estimates on variables with only moderate changes over time. This latter feature is somewhat present for some of our control variables (e.g., the size of each economy changes only slowly over time), but does not affect our migration variable, for which the within-variation is as large as the between-variation. The benefit of this dynamic approach is, however, that the model stresses whether a change in a given right-hand side variable is related to a change in the dependent variable. Hence, 
we can assess whether an increase in refugees will influence subsequent growth of the low-wage occupations.

\section{Immigration and growth of low-wage work}

Figure 1 shows the development of refugee immigration to the EU15 countries during the post-war period. Starting in the early 1950s, the number of refugees within the EU15 was close to 1.3 million. In the following two decades, the number declined and levelled out at 0.5 million in the late 1970s. The situation changed dramatically in the 1980s, as the number of refugees increased rapidly during the Iran-Iraq war. The breakdown of the Soviet Union and the subsequent war in the Balkans led to another major change in the refugee situation. In the early 1990s, close to 2.2 million individuals with protected status as refugees lived in the EU15 countries.

The number of individuals registered as refugees declined by 430 thousand from the mid-1990s up until the early 2010s. Some returned, while others naturalized. Looking at the reports from UNHCR, the former seems to be less common, although there could be an issue of underreporting returns. In turn, the total number of immigrants from the Balkans increased by 320 thousand within the same period. This implies that, in addition to people being naturalized, immigration from the Balkans has continued during the past two decades. This development is however more related to labour market opportunities than to exogenously driven growth of labour supply.

The number of people with refugee status in the EU15 dropped substantially from the early 1990s onwards. By the early 2010s, the figure was down to 1 million. However, the situation changed with the Syrian war. The number of refugees increased to the highest figure since WWII, when almost 2.5 million individuals with international protected refugee status lived in the EU15 countries. The number of refugees was not distributed equally, but largely carried by a few countries. As shown in Fig. 2, the largest share of refugees in relation to population was found in the Nordic countries. Continental Europe hosted the largest number of refugees in absolute numbers, but a lower share in relation to population size. Both the absolute number and the share of refugees in relation to population were lower in Southern Europe and in the UK and Ireland. The share of refugees today largely mirrors the situation in the early 1990s. Just as today, the Nordic countries had a refugee share of the population close to $1.4 \%$. Continental Europe had a somewhat higher share of refugees in the early 1990s (1\%) compared to today $(0.9 \%)$. Southern Europe along with the UK and Ireland have a slightly higher share of refugees today (2\%) compared to the situation in the early 1990s (1\%).

While refugee immigration is related to exogenous chocks, the demand for labour has been another driver of the immigration flow to the EU economies. As shown in Fig. 3, the share of immigrants of total employment has increased by close to 10 percentage points in the Nordic countries as well as Southern Europe together with Ireland and the UK. Today, immigrants make up close to $15 \%$ of employment in the EU15 countries. Continental Europe already had a high immigrant share of employment in the mid-1990s, but has seen less changes since then. Most of the increase in immigrant labour is related inter-EU labour mobility, and labour inflow from other high- and middle-income countries. Less of the increase is related to labour mobility from low-income countries outside the EU. The largest increase is seen in the Nordic 


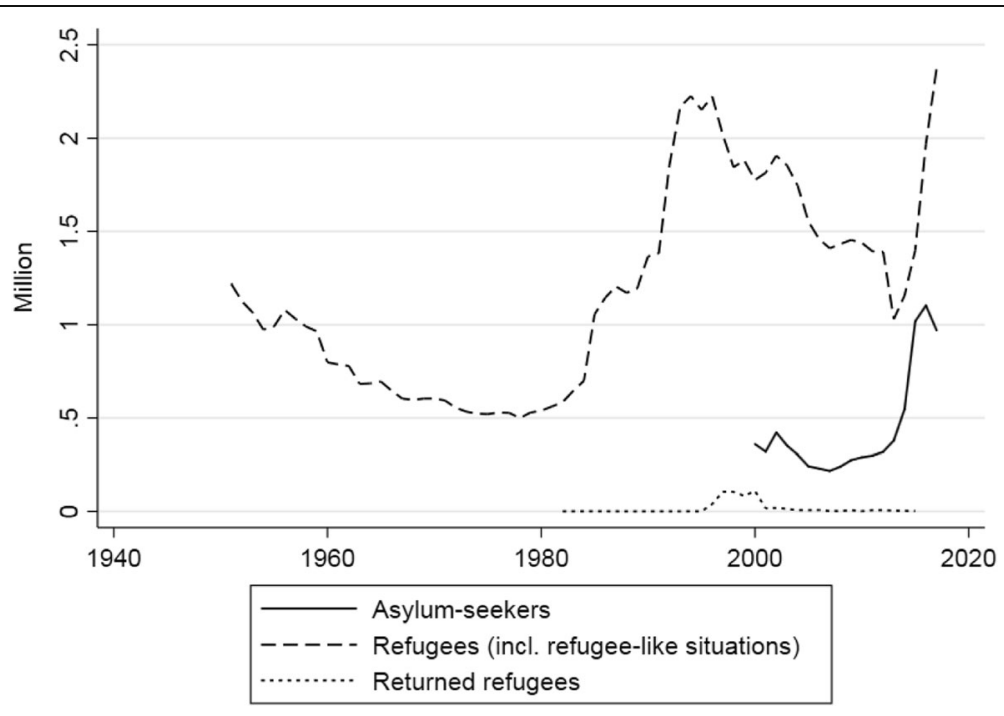

Fig. 2 Number of refugees in the EU15 countries between 1951 and 2017. Source: UNHCR, time series. Note 1: Refugees are people who are recognized as refugees under the 1951 Convention Relating to the Status of Refugees or its 1967 Protocol, the 1969 Organization of African Unity Convention Governing the Specific Aspects of Refugee Problems in Africa, people recognized as refugees in accordance with the UNHCR statute, people granted refugee-like humanitarian status, and people provided temporary protection. Note 2: EU 15 with Luxemburg excluded and Norway and Switzerland included. Continental Europe (Austria, Belgium, France, Germany, Netherlands and Switzerland). Southern Europe (Greece, Italy, Portugal, Spain); Nordic region (Denmark, Finland, Norway, Sweden); the UK and Ireland

countries, with an increase in the share of workers from outside the EU from $0.4 \%$ in the mid-1990s to $1.6 \%$ today.

The descriptive statistics show that the lion's share of immigration is related to a largely demand-driven increase in immigrants. The exogenously driven change in the supply of labour, most clearly related to refugee immigration, amounts to a much lower proportion. Even when we expand the scope to include all non-EU immigrants from

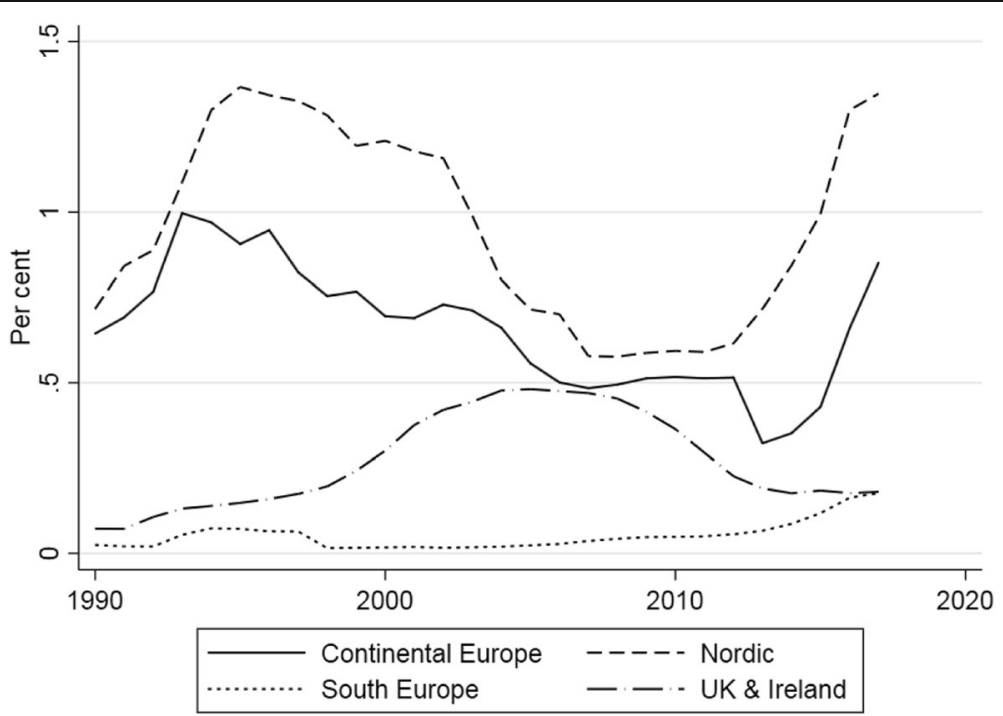

Fig. 3 Refugee share of population in EU15 by regions between 1990 and 2017. Source: UNHCR, time series; UN: World Development Indicators. Note: See Fig. 1 for definitions 
low-income countries, a group that represents a mix of demand and exogenously driven causes, the increase is less than from the demand side. If the latter immigration is to matter for the growth of low-wage work, the impact needs to be far greater than that based on demand-driven causes.

In line with previous studies using European data (e.g., Goos et al., 2014), Fig. 4 shows that the low-wage sector has grown more than average employment during the past two decades. In the Anglo-Saxon countries, the employment growth in low-wage occupations (ISCO 5 \& 9), normalized by total employment growth, was on average 0.9\% between 1995 and 2017. Continental European economies have seen a similar growth rate in low-wage occupations, while the low-wage sectors in the Nordic countries have experienced less of an expansion (0.4\%). In Southern European countries, the sector has expanded more. Thus, while the type of immigrants differ across these macro-regions in the EU, so does also the expansion of the low-wage sector. While this could be associated with different global and technological changes influencing the presence of low-wage occupations (Farkas, 2016; Goos et al., 2014), it is likely also associated with different institutional settings between countries.

\section{Impact of immigration on low-wage work}

Table 1 presents the regression results. They are presented in a stepwise manner in a total of four different models, each divided in a-c, in which the entire low-wage sector is estimated (a), followed by service jobs (b) and elementary occupations (c). First, Model 1 estimates the main effect of refugee migrants, while Model 2 interacts the migration variable with the EU25 dummy to capture whether the change in low-wage occupations is influenced by EU enlargement (demand driven) or refugees as such (supply driven). Model 3 then shows the interaction effect between refugees and investments as a share of GDP to assess whether a process of capital adjustment is indeed occurring that can accommodate the increasing supply of labour. Finally, Model 4

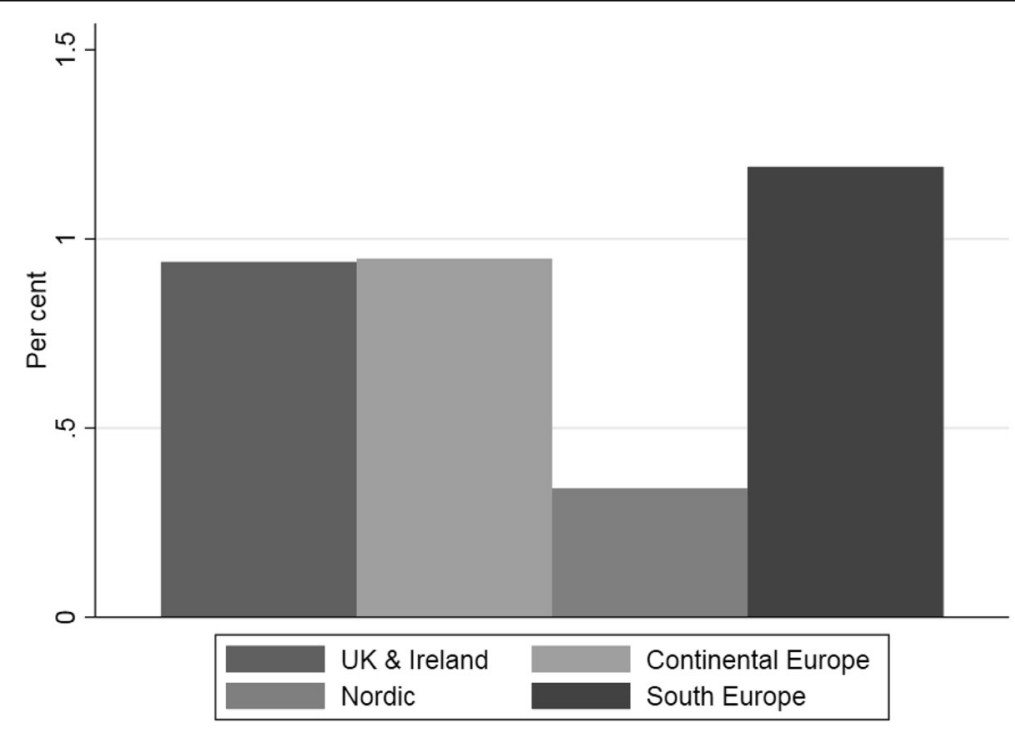

Fig. 4 Annual growth in low-wage occupations normalized by total employment growth in EU15 regions during the period 1995 to 2017. Source; EUROSTAT, LFS. OECD, Demography and Population. Note; Low wage occupations is defined as ISCO 5 (Service workers) and ISCO 9 (Elementary occupations) 


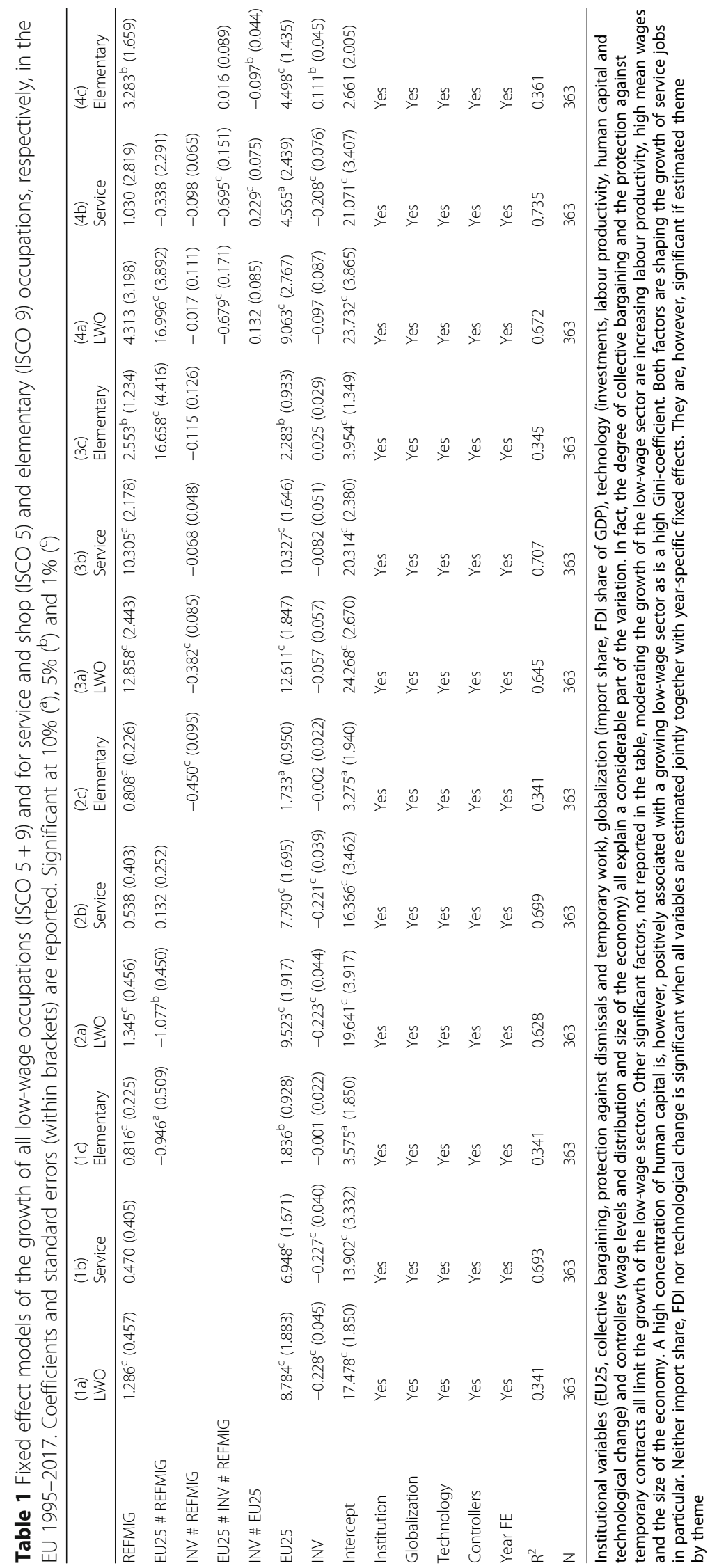


displays a three-way interaction between share of refugees, investments and EU enlargement.

As shown in Table 1, an increasing share of refugees is indeed associated with a relative increase in low-wage occupations. This is, however, primarily the case concerning elementary occupations (c). On the other hand, EU enlargement, as captured by the EU25 dummy, indicates that this mainly influences the supply of service sector jobs and not elementary jobs. Expanding economies, proxied as high investment rates, generally experience a declining low-income share. The notion that EU enlargement itself induced a relative growth in service jobs is confirmed in Model 2, where refugees are interacted with the EU25 dummy. The main effects of refugees and EU25 are largely unaffected (somewhat larger coefficients for all jobs in both cases and elementary jobs for refugees and service jobs concerning EU25), while the interaction between refugees and EU25 is negative. Hence, refugees per se tend to mainly be associated with an increase in elementary occupations with low formal thresholds, while service jobs are occupied by EU migrants to a greater extent.

Further, the estimations from Model 3 confirm the notion that a high share of investments impedes the growth of the low-wage sector. This is particularly the case concerning high rates of refugees. In other words, we can confirm $\mathrm{H} 2$, which states that in cases of capital adjustment, the low-wage sector does not grow as a consequence of increasing labour supply. This applies only to the case of service jobs (b), however, and not to elementary occupations (c), for which the interaction between investments and refugees has no impact. As a final test of the effect of EU enlargement and investment on the role of refugee migration in the relative growth of low-wage jobs, we have conducted a three-way interaction between refugees, EU25 and investments (Model 4). The main outcome of this is the finding that refugees per se do not influence the growth of the share of low-wage jobs (service jobs in particular), but that this practically only occurs in economies that, after EU enlargement, have low investment rates. Concerning the growth of elementary occupations, the story is somewhat different. Increasing shares of refugees also imply increasing shares of elementary occupations. However, this is mitigated in economies with high investments after the EU enlargement. Because the main effect of investments turns negative, it is clear that this is the case before EU enlargement.

However, as shown in Figs. 3 and 5, different economies have experienced different inflows of migrants due to their relative location, welfare regimes and openness towards refugees. To assess whether these varying trajectories have had an impact on low-wage occupations in the respective country groups, we estimate 2 additional models where a dummy representing each regional group is interacted with REFMIG. As these variables are time invariant, it is not possible to directly estimate them in a fixed effect model. To acknowledge this shortcoming, Table 2 presents the marginal effects obtained from fixedeffect models in which REFMIG is interacted with all of the country groups in the same model. By splitting the dependent variable into service and shop workers and elementary occupations, the sum of the second and third column corresponds with the score in the first column (combined). Because a significant contrast indicates whether differences in means across groups are significant, we find that when estimating all country group interactions jointly, by far the greatest impact on growth of the share of low-wage jobs is found in Southern Europe and the UK and Ireland (Model 5a). In immigration regions like Continental Europe and the Nordic countries, the effects are far smaller. In fact, there is no 

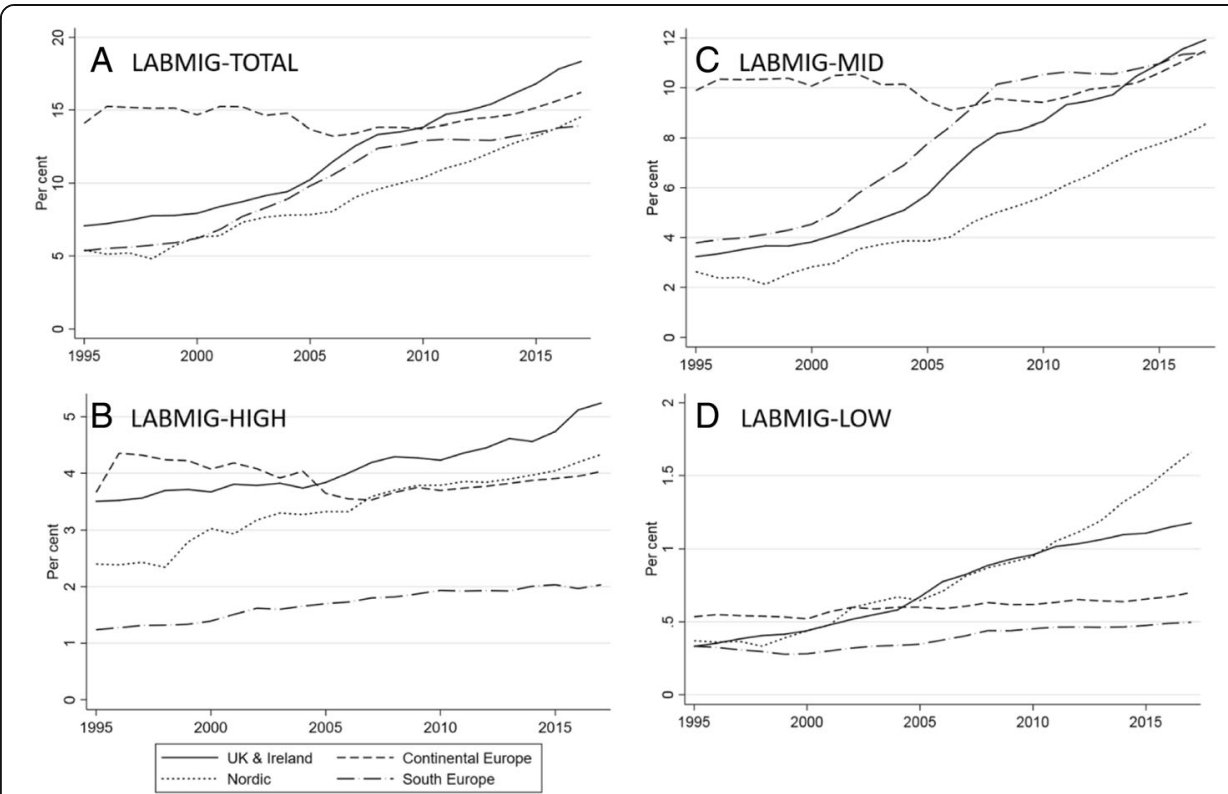

Fig. 5 Immigrant share of employment in EU15 by origin between 1995 and 2017. Source: EUROSTAT, LFS. OECD. Note: See Fig. 2 for definitions. a LABMIG-TOTAL b LABMIG-HIGH c LABMIG-MID d LABMIG-LOW

statistical relationship between refugee migration and an increasing share of low-wage jobs in the Nordic countries. While the positive association between refugee migrants and an increasing share of low-wage jobs is significant in Southern Europe, there are stark differences between which types of low-wage jobs are increasing in shares in the different country groups. When we split the sample into service occupations and elementary

Table 2 Pairwise comparisons of marginal linear predictions obtained from fixed effect models of refugee migrants on all low-wage occupations (ISCO $5+9)$ and for service and shop (ISCO 5) and elementary (ISCO 9) occupations, respectively. Marginal effects and standard errors (within brackets) are reported for annual changes (5) and at 5-year intervals (6). Significant at 10\% ( ${ }^{\mathrm{a}}$ ), 5\% $\left({ }^{b}\right)$ and $1 \%\left({ }^{c}\right)$

\begin{tabular}{|c|c|c|c|c|c|c|}
\hline & $\begin{array}{l}(5 a) \\
\text { LWO }\end{array}$ & $\begin{array}{l}(5 b) \\
\text { Service }\end{array}$ & $\begin{array}{l}(5 \mathrm{c}) \\
\text { Elementary }\end{array}$ & $\begin{array}{l}(6 a) \\
\text { LWO }\end{array}$ & $\begin{array}{l}(6 b) \\
\text { Service }\end{array}$ & $\begin{array}{l}\text { (6c) } \\
\text { Elementary }\end{array}$ \\
\hline REFMIG \# UK \& IRL & $6.852^{c}(2.397)$ & $0.916(2.217)$ & $\begin{array}{l}5.936^{\mathrm{C}} \\
(1.233)\end{array}$ & $4.139(7.393)$ & $\begin{array}{l}-6.314 \\
(6.214)\end{array}$ & $\begin{array}{l}10.453^{b} \\
(3.909)\end{array}$ \\
\hline $\begin{array}{l}\text { REFMIG \# } \\
\text { CONTINENTAL }\end{array}$ & $\begin{array}{l}1.482^{b} \\
(0.641)\end{array}$ & $\begin{array}{l}1.169^{b} \\
(0.593)\end{array}$ & $\begin{array}{l}0.313 \\
(0.330)\end{array}$ & $1.797(1.931)$ & $0.967(1.623)$ & $0.831(1.021)$ \\
\hline REFMIG \# NORDIC & $0.118(0.528)$ & $\begin{array}{l}-0.391 \\
(0.488)\end{array}$ & $\begin{array}{l}0.508^{a} \\
(0.272)\end{array}$ & $0.564(1.385)$ & $\begin{array}{l}-0.524 \\
(1.164)\end{array}$ & $1.089(0.732)$ \\
\hline REFMIG SOUTH & $\begin{array}{l}24.238^{c} \\
(3.165)\end{array}$ & $\begin{array}{l}17.144^{c} \\
(2.927)\end{array}$ & $\begin{array}{l}7.094^{\complement} \\
(1.629)\end{array}$ & $\begin{array}{l}32.922^{c} \\
(5.971)\end{array}$ & $\begin{array}{l}26.957^{c} \\
(5.019)\end{array}$ & $5.965^{\mathrm{a}}(3.157)$ \\
\hline Institution & Yes & Yes & Yes & Yes & Yes & Yes \\
\hline Globalization & Yes & Yes & Yes & Yes & Yes & Yes \\
\hline Technology & Yes & Yes & Yes & Yes & Yes & Yes \\
\hline Controllers & Yes & Yes & Yes & Yes & Yes & Yes \\
\hline Year FE & Yes & Yes & Yes & Yes & Yes & Yes \\
\hline $\mathrm{R}^{2}$ & 0.694 & 0.729 & 0.415 & 0.713 & 0.786 & 0.485 \\
\hline $\mathrm{N}$ & 363 & 363 & 363 & 80 & 80 & 80 \\
\hline
\end{tabular}

1: Model 6a-c are estimated at 5-year intervals over the years 1997, 2002, 2007, 2012 and 2017

2: The following variables are included: institutional (EU25, collective bargaining, protection against dismissals and temporary work), globalization (import share, FDI share of GDP), technology (investments, labour productivity, human capital and technological change) and controllers (wage levels and distribution and size of the economy) 
occupations (Models 5b and c), we find that the relative growth of service occupations is positively associated with refugee migration in Continental Europe, while in the UK and Ireland refugee migration mainly affects elementary occupations. The latter is also true for the Nordic countries, although the effect is small and only significant at the $10 \%$ level.

It is, however, reasonable to expect that the labour market effect of refugee migrants is not instantaneous, and despite lagging all right-hand side variables, we may have chosen a too tight time window for any effects to materialize. Therefore, the final set of models in Table 2 are based on estimations using 5-year intervals. Neither significant effects in Continental Europe nor in the Nordic countries remain, while the effects in the UK and Ireland grow stronger for elementary occupations. This is also the case for service occupations in Southern Europe. The results suggest that a one percentage point increase in the refugee migration share translates to a 10 percentage point increase in elementary occupations in the UK and Ireland and 6 percentage points in Southern Europe, when controlling for a number of country-specific characteristics. The effect is, however, far greater on service occupations in Southern Europe, as a one percentage point increase in the refugee migration share in 5 years translates to a 27 percentage point increase in service occupations.

Finally, as shown in Table 3, when we regress the impact of different types of origins among the employed population in each economy, these main findings on refugees (Model 5a-5c) correspond to the models on immigration shares from different income countries (Model 7a-7c). The growth of low-wage occupations is only related to an increase in migrants from low-wage countries in the UK and Ireland, and in migrants from high-income countries in Southern Europe. Hence, when we include all foreign-born individuals, the results indicate that immigration from low-wage countries does indeed have a similar general association with increasing low-wage occupations in the UK and Ireland, but that low-wage work in the southern parts of Europe is more demand driven (i.e., an increasing share of migrants from high-income countries increases the demand for low-wage jobs). When separating service jobs (Model 7b) from elementary jobs (Model 7c), this is even more pronounced, as service jobs are increasing in the south due to high-income immigration and elementary jobs due to middle-income immigration (i.e., EU25 excluding EU15 and non-EU countries with similar income levels). However, there are two obvious differences between the refugee effect and the labour migration effect. First, the original positive estimation in Continental and Nordic countries (Model 5) disappears when we separate the origin of all workers. Hence, refugee migration, not immigration per se, does indeed have a shortterm effect on the low-wage sectors in Continental and Nordic countries, although without a long-term effect (5 years), as shown in Model 6 (Table 2). Second, the positive effect on refugee migration and low-wage jobs that was mainly attributable to elementary jobs is not present when all immigrants are considered. Instead, it is mainly service jobs that grow in relation to labour migration from low-wage countries.

Thus, to summarize, persistent within-EU variations (Farkas, 2016) do indeed influence the potential mechanisms leading to the growing share of low-wage occupations, and it is only in the UK and Ireland as well as in Southern Europe where some support for the Rybczynski theorem can be found. This could be attributed to lower shares of investments in the UK and Ireland and Southern Europe, but also to lower levels of social mobility compared to, for example, the Nordic countries (Eurofound, 2017). This would consequently impede the potential bumping up effect of natives from low-wage jobs. 
Table 3 Pairwise comparisons of marginal linear predictions obtained from fixed effect models of different types of migrants on all low-wage occupations (ISCO $5+9)$ and for service and shop (ISCO 5) and elementary (ISCO 9) occupations, respectively. Marginal effects and standard errors (within brackets) are reported. Significant at 10\% $\left({ }^{\mathrm{a}}\right), 5 \%\left({ }^{\mathrm{b}}\right)$ and $1 \%\left({ }^{\mathrm{c}}\right)$

\begin{tabular}{llll}
\hline & LWO & (7b) & (7c) \\
& LWO & Service & Elementary \\
\hline LABMIG HIGH \# UK \& IRL & $-1.012^{\mathrm{b}}(0.327)$ & $-0.531^{\mathrm{a}}(0.268)$ & $-0.481^{\mathrm{a}}(0.187)$ \\
LABMIG HIGH \# CONTINENTAL & $-0.618^{\mathrm{b}}(0.225)$ & $-0.425^{\mathrm{a}}(0.185)$ & $-0.193(0.129)$ \\
LABMIG HIGH \# NORDIC & $-0.402(0.333)$ & $0.403(0.274)$ & $-0.805^{\mathrm{c}}(0.190)$ \\
LABMIG HIGH \# SOUTH & $3.125^{\mathrm{c}}(0.749)$ & $4.826^{\mathrm{c}}(0.615)$ & $-1.701^{\mathrm{c}}(0.428)$ \\
LABMIG MID \# UK \& IRL & $-1.848^{\mathrm{b}}(0.593)$ & $-1.226^{\mathrm{a}}(0.487)$ & $-0.622(0.339)$ \\
LABMIG MID \# CONTINENTAL & $-0.852(0.523)$ & $-0.449(0.430)$ & $-0.403(0.299)$ \\
LABMIG MID \# NORDIC & $-2.612^{\mathrm{c}}(0.473)$ & $-2.750^{\mathrm{c}}(0.389)$ & $0.138(0.270)$ \\
LABMIG MID \# SOUTH & $0.173(0.522)$ & $-1.063^{\mathrm{a}}(0.429)$ & $1.236^{\mathrm{c}}(0.298)$ \\
LABMIG LOW \# UK \& IRL & $16.444^{\mathrm{b}}(5.497)$ & $10.860^{\mathrm{a}}(4.519)$ & $5.584(3.140)$ \\
LABMIG LOW \# CONTINENTAL & $-0.439(0.515)$ & $-0.268(0.423)$ & $-0.170(0.294)$ \\
LABMIG LOW \# NORDIC & $-0.508^{\mathrm{b}}(0.184)$ & $-0.428^{\mathrm{b}}(0.152)$ & $-0.080(0.105)$ \\
LABMIG LOW \# SOUTH & $-0.809^{\mathrm{b}}(0.312)$ & $-0.581^{\mathrm{a}}(0.256)$ & $-0.228(0.178)$ \\
Institution & Yes & Yes & Yes \\
Globalization & Yes & Yes & Yes \\
Technology & Yes & Yes & Yes \\
Controllers & Yes & Yes & Yes \\
Year FE & Yes & Yes & Yes \\
R ${ }^{2}$ & 0.713 & 0.742 & 0.423 \\
N & 363 & 363 & 363 \\
\hline
\end{tabular}

The following variables are included: institutional (EU25, collective bargaining, protection against dismissals and temporary work), globalization (import share, FDI share of GDP), technology (investments, labour productivity, human capital and technological change) and controllers (wage levels and distribution and size of the economy)

\section{Concluding remarks}

Our main empirical findings indicate that the growing share of refugees, as well as immigration more generally, has only had a limited general impact on the growth of the low-wage sector in the EU during the past two decades. The main drivers behind increasing labour market polarization and growth of the low-wage sector in particular seem to be more related to technological changes, institutions and globalization (Fernandez-Macias \& Hurley, 2017; Goos et al., 2009). Our findings are thus largely in line with Autor and Dorn (2013) study on the US, showing that growing low-skilled migration had much less impact than the aforementioned factors on the expansion of lowskilled occupations.

When considering the effect of refugees on the growth of low-wage occupations, we do find a significant association between the two. In general, however, this is attributed to elementary occupations with presumably lower skill or native language mastery requirements as compared to more interactive service and retail occupations. Our results suggest that European enlargement is associated with the relative growth of service occupations to a great extent, but not as a consequence of increasing refugee migration. Hence, this points to a more demand-driven flow from new member states to EU15 countries (e.g., from CEE countries to the UK and Ireland). In particular, there is a clear association with the rate of 
investments and the share of refugees, as expanding economies show less of a relationship between refugee migration and the relative growth of low-wage occupations. Most apparent is the positive impact of refugees on the expanding low-wage sector in the UK and Ireland and in Southern Europe, and the largely insignificant impact in Continental and Nordic countries. These findings are largely confirmed when we not only include refugees, but all immigrants based on their origin. While the former confirms the arguments derived from the Rybczynski theorem, it could also be associated with firms facing less incentives to adopt skilled-biased technologies when low-skilled labour is abundant and when the wage gap is greater compared to the other macro-regions (Algan et al., 2010; Lewis, 2011). Hence, given the structure of immigrant workers and institutional settings, the impact of immigration on the expanding low-wage sector differs.

The weak impact of refugee migration on the low-wage sectors in the other macroregions could also be related to adjustment mechanisms. One reason could be the general possibility of social mobility, in particular the upward mobility of native workers. When immigrant workers enter more manual and less skill-demanding work, native workers may be reallocated to more skill-demanding occupations. As suggested by, for example, Foged and Peri (2016), this is because natives are offered new career possibilities and migrants will take over low-wage manual work when the economy expands. As our findings on the interaction effect between investments and refugee migrants suggest, the upward mobility of native workers may further be due to the capital adjustment mechanism advocated by Tabellini (2018).

The weaker capital adjustment mechanism in the UK and Ireland could be attributed to different institutional factors. Relatively weaker labour unions pushing down wages on lowskilled work may be one reason for expanding such sectors. Another plausible explanation is linked to the educational system. As argued by Eurofound (2017), greater inequality in schooling may create different opportunities among groups in society. Low human capital endowments among native low-wage workers may turn negative for social mobility and an associated wage career, making upskilling less feasible.

Our findings underline the importance of re-considering not only the impact of immigration on overall occupational structures, but in particular the impact of refugee migration. This has implications for how we should think about the potential effect on public finance. Only translating the presence of refugees in low-wage occupations into lower taxable incomes, while overlooking the influence of upward mobility on native workers' taxable incomes, will probably bias fiscal accounting with regard to exogenously driven refugee immigration. Instead, our findings show that the impact of refugee migration on the low-wage sector varies across different institutional regimes. In fact, while the Rybczynski theorem holds some merit in the UK and Ireland due to their lower minimum wages and less social mobility, the notion of potential upgrading of natives seems to be more valid in regimes with more compressed income structures and greater potential for social mobility (cf. Foged \& Peri, 2016). In short, integration of refugees is highly dependent on broader integration policies. To further delve into this issue, micro-data that enable separation of the occupations of native workers from those of immigrants are required (cf. Foged \& Peri, 2016). If this were done, the effect of immigration on the occupation structure of natives and immigrants, respectively, could be assessed as a function of country of origin. The main limitation of the present study is that we only can analyse the overall occupation structure in each economy. 


\section{Appendix}

Table 4 Full variable list with description and source

\begin{tabular}{|c|c|c|}
\hline Variable & Description & Source \\
\hline \multicolumn{3}{|c|}{ Dependent variables } \\
\hline LowWage & Low wage occupation (ISCO 5 \& 9) share of total employment \% & EUROSTAT \\
\hline ServiceShop & Low wage occupation (ISCO 5) share of total employment \% & EUROSTAT \\
\hline Elementary & Low wage occupation (ISCO 9) share of total employment \% & EUROSTAT \\
\hline \multicolumn{3}{|l|}{ Migration } \\
\hline TOT & Share of foreign born employed, in \% of total employed & $\begin{array}{l}\text { EUROSTAT, } \\
\text { OECD, UN }\end{array}$ \\
\hline $\begin{array}{l}\text { LABMIG } \\
\text { HIGH }\end{array}$ & $\begin{array}{l}\text { Share of foreign born employed from high-income countries as \% of total } \\
\text { employed }\end{array}$ & $\begin{array}{l}\text { EUROSTAT, } \\
\text { OECD, UN }\end{array}$ \\
\hline $\begin{array}{l}\text { LABMIG } \\
\text { MID }\end{array}$ & $\begin{array}{l}\text { Share of foreign born employed from new EU, or medium income countries, } \\
\text { as \% of total employed }\end{array}$ & $\begin{array}{l}\text { EUROSTAT, } \\
\text { OECD, UN }\end{array}$ \\
\hline $\begin{array}{l}\text { LABMIG } \\
\text { LOW }\end{array}$ & $\begin{array}{l}\text { Share of foreign born employed from low income countries (refugee } \\
\text { migrants) as \% of total employed }\end{array}$ & $\begin{array}{l}\text { EUROSTAT, } \\
\text { OECD }\end{array}$ \\
\hline REFMIG & Share of refugee migrants as \% of total population & UN \\
\hline \multicolumn{3}{|l|}{ Institutional } \\
\hline EU25+ & EU25_Period (2004-2015 = 1, 0 otherwise) & EUROSTAT \\
\hline GINI & Gini coefficient of equalized disposable income & EUROSTAT \\
\hline CollBar & Adjusted bargaining coverage rate: proportion of all wage & OECD \\
\hline EmpDis & Protection against dismissals & OECD \\
\hline EmpTemp & Protection against temporary employment & ICTWSS \\
\hline \multicolumn{3}{|l|}{ Globalization } \\
\hline ImpShare & Import to GDP share in $\%$ & $\begin{array}{l}\text { Penn World } \\
\text { Tables }\end{array}$ \\
\hline FDI & Outward foreign direct investments as proportion of GDP & OECD \\
\hline \multicolumn{3}{|l|}{ Technology } \\
\hline LP & Labour productivity & OECD \\
\hline $\mathrm{HC}$ & Human capital level (pwt) & $\begin{array}{l}\text { Penn World } \\
\text { Tables }\end{array}$ \\
\hline TechChange & Technological change defined as total factor productivity growth & $\begin{array}{l}\text { Penn World } \\
\text { Tables }\end{array}$ \\
\hline INV & Investments as share of GDP & OECD \\
\hline \multicolumn{3}{|l|}{ Controllers } \\
\hline RelWage & Relative wage (country wage to EU average) \% & OECD \\
\hline LMsize & Labour market size (number employed in thousands) & OECD \\
\hline
\end{tabular}

\section{Acknowledgements}

The manuscript has benefited from comments received by Professor Eskil Wadensjö and participants at the Umeå University Conference on Mobility, Economic Transformation. However, the normal disclaimer applies.

\section{Authors' contributions}

LFA has managed data and provided the descriptive (part of) theory and introduction section. RE has made the econometric analysis and provided the result section. SS has provided part of the introduction and theory section and revised the final version of the manuscript. The authors has jointly discussed and put out the outline of the manuscript. All authors read and approved the final manuscript.

\section{Funding}

The research work (salaries) has been granted by Arenagruppen, Arenaide, Sweden. The researchers have independently from the funding body carried out the design of the study and collection, analysis, and interpretation of data. The writing of the manuscript has been carried out independently from the funding body. 
Availability of data and materials

The data are publicly available. A list of sources by variable is provided in Appendix.

\section{Competing interests}

The authors declare that they have no competing interests.

\section{Author details}

'Department of Economic History \& Centre for Demographic and Ageing Research, Umeå University, Biblioteksgränd 6,

SE-90187 Umeå, Sweden. ²Department of Geography, Umeå University, Biblioteksgränd 6, SE-90187 Umeå, Sweden.

${ }^{3}$ Arenagruppen, Arenaide, Stockholm, Sweden.

Received: 1 February 2019 Accepted: 15 July 2019

Published online: 11 September 2019

\section{References}

Algan, Y., Dustmann, C., Glitz, A., \& Manning, A. (2010). The economic situation of first and second-generation immigrants in France, Germany and the United Kingdom. The Economic Journal, 120(1), F4-F30.

Autor, D.H., \& Dorn, D. (2013) The Growth of Low-Skill Service Jobs and the Polarization of the US Labor Market. American Economic Review 103(5), 1553-1597. Retrieved from https://www.ddorn.net/papers/Autor-Dorn-LowSkillServicesPolarization.pdf.

Borjas, G. J. (2003). The labor demand curve is downward sloping: Re-examining the impact of immigration on the labor market. Quarterly Journal of Economics, 118(4), 1335-1374.

Brinley, T. (1954). Migration and economic growth: A study of Great Britain and the Atlantic economy. Cambridge: Cambridge Univ.

Card, D. (2001). Immigrant inflows, native outflows and the local labor market impacts of higher immigration. Journal of Labor Economics, 19, 22-64.

Card, D. (2005). Is the new immigration really so bad? The Economic Journal, 115, 300-323.

Dustmann, C., Hatton, T., \& Preston, I. (2005). The labour market effects of immigration. The Economic Journal, 115, 297-299.

Dustmann, C. \& Frattini, T. (2011). Immigration: The European Experience (CReAM, Discussion Paper No. 6261). Retrieved from http://ftp.iza.org/dp6261.pdf.

Dustmann C., \& Glitz A. (2015). How Do Industries and Firms Respond to Changes in Local Labor Supply?. Journal of Labor Economics 33(3), pp. 711-750.

Ekberg, J. (2011). Will future immigration to Sweden make it easier to finance the welfare system? European Journal of Population, 27, 103-124.

Eurofound (2017). Social mobility in the EU. Luxembourg: Publications Office of the European Union.

Eva, M.-G., \& Tritah, A. (2016). The effects of immigration in frictional labor markets: Theory and empirical evidence from EU countries. European Economic Review, 84, 76-98.

Farkas, B. (2016). Models of capitalism in the European Union post-crisis perspectives. Palgrave Macmillan.

Fernandez-Macias, E., \& Hurley, J. (2017). Routine-biased technical change and job polarization in Europe. Socio-Economic Review, 15(3), 563-585.

Foged, M., \& Peri, G. (2016). Immigrants' effect on native workers: New analysis on longitudinal data. American Economic Journal: Applied Economics, 8(2), 1-34.

González, L., \& Ortega, F. (2011). How do very open economies adjust to large immigration flows? Evidence from Spanish regions. Labour Economics, 18, 57-70.

Goos, M., Manning, A., \& Salomons, A. (2009). Job polarization in Europe. American Economic Review: Papers \& Proceeding, 99(2), 58-63.

Goos, M., Manning, A., \& Salomons, A. (2014). Explaining job polarization: Routine-biased technological change and offshoring. American Economic Review: Papers \& Proceeding, 104(8), 2509-2526.

Harris, J. R., \& Todaro, M. P. (1970). Migration, unemployment and development. A two-sector analysis. American Economic Review, 60(1), 126-142.

Hatton, T. J. (2016). The migration crisis and refugee policy in Europe. In F. Fasani (Ed.), Refugees and economic migrants: Facts, policies and challenges. Vox CEPR Press.

Lewis, E. (2011). Immigration, skill mix, and capital-skill complementarity. Quarterly Journal of Economics, 126(2), 1029-1069.

OECD (2017a). International migration outlook 2017. Paris: OECD publishing.

OECD (2017b). Finding their Way: Labour Market Integration of Refugees in Germany. OECD. Retrieved from https://www.oecd. org/els/mig/Finding-their-Way-Germany.pdf.

Ottaviano, G., \& Peri, G. (2012). Rethinking the effects of immigration on wages. Journal of the European Economic Association, 10(1), 152-197.

Rodriguez-Planas N. (2012) Wage and occupational assimilation by skill level: migration policy lessons from Spain. IZA Journal of European Labor Studies 1(1), p. 8. https://doi.org/10.1186/2193-9012-1-8.

Rybczynski, T. M. (1955). Factor Endowment and Relative Commodity Prices, Economica 22(88),336.

Seukwa, L. H. (2013). Integration of refugees into the European education and labour market. Peter Lang Publishing Group.

Tabellini, M. (2018). Gifts of the Immigrants, Woes of the Natives: Lessons from the Age of Mass Migration. Online Appendix B. (MIT Job Market Paper). Retrieved from https://economics.mit.edu/files/13523.

Venturini, A., \& Villosio, C. (2006). Labour market effects of immigration into Italy: An empirical analysis. International Labour Review, 145(1-2), 91-118.

\section{Publisher's Note}

Springer Nature remains neutral with regard to jurisdictional claims in published maps and institutional affiliations. 